\title{
What IS A CRIME? DEFINING CRIMINaL ConduCt IN CONTEMPORARY SOCIETY, LaW COMmISSION OF CaNada, ED. (VANCOUVER: UNIVERSITY OF BRITISH COLUMbia Press, 2004)
}

As we read in the introduction penned by Dean Nathalie Des Rosiers, formerly the Chair of the Law Commission of Canada, and Steven Bittle. a senior research officer at the Law Commission of Canada, the question "What Is A Crime?" is an important question in that it addresses why certain behaviours are not criminalized, notably corporate wrongdoing in many instances, as much as it seeks to explain why society has made certain acts punishable. The essays found in this collection employ a range of critical perspectives in seeking to examine crime and its control in contemporary society and the resulting diversity of approaches is quite beneficial in providing both a healthy mix of perspectives and in illustrating a great number of seemingly paradoxical conclusions.' What emerges is a profound belief that the criminal law as a blunt instrument of social control must be resorted to in far fewer instances in respect of general behaviour and made far sharper and effective with a view to cutting into a legion of socially harmful conduct well-nigh oblivious to control at present. ${ }^{2}$ Given the general and specific nature of the criticisms articulated by the editors and authors in this volume, no doubt they would agree without hesitation with the view expressed by Professor Lucia Zedner: "[D]efinitions of crime are historically and politically contingent ... [Scholarship seeks] to reveal the power relationships and political imperatives that underlie criminalization."

In this respect, I begin by noting the excellence of the first essay, "What Is A Crime? A Secular Answer," written by Professeur Jean-Paul Brodeur, a highly respected member of the Centre international de criminologie comparée of the Université de Montréal, and his collaborator, Geneviève Ouellet. Indeed, the superior quality of any enterprise is often dependent on the merits of the initial work or introductory chapter and the signal value of this opening chapter needs to be underscored. In effect, in the same way that a chapter should be well introduced by the opening paragraph and the paragraph be explained by the initial sentence, this superb prolegomenon assures the reader that the time spent on reading the volume will be well invested. This conclusion rests on two observations. On the one hand, the skill with which the authors set out the various parameters to the within discussion is worthy of commendation as is the reasoning behind the selection of the various thematic divisions. Not only is the casual reader well initiated into the subject matter at hand, the professional criminologist will find interesting summaries of the state of various controversies involving both the victim and the offender. Further, the discussion of criminalization as communication is a surprisingly poorly discussed area in contemporary

\footnotetext{
1 The reader is asked to recall the lessons of present-day criminology to the effect that paradoxes and apparent contradictions are often seen as commonplace whenever the State seeks to resort to its criminal law power to achieve a socially desirable purpose, as made plain in the introductory passinge and inamy of the essays found in Richard Hil \& (jordon Tait. eds. Mard Lessons: Reflections on Governance and (rime Control in Late Moderm!) (Burlington. Vt: Asligate, 2004). A simple cxample is found al 2 "[N]or should we be shocked when things 'go wrong' in the domain of crime control since matly unintended consequences are, more often than not, quite predictahle." 
Canadian literature and the comments at pages 17 and 28 are most welcome. ${ }^{4}$ Further, the review of legal formalism including the emerging issue of the sharia or Islamic law" is quite helpful in situating current controversies and in anticipating future developments. Finally, the discussion at pages 23-28 under the rubric of "Guilty Monopolies" is valuable in explaining the contemporary issues touching upon gambling and in illustrating how the criminal law may be fairly accused of negative discrimination.

The next contribution, "Undocumented Migrants and Bill C-11: The Criminalization of Race," by Professor Wendy Chan of the School of Criminology, Simon Fraser University, is a hard-hitting and no-holds-barred indictment of the use of criminal law to bring about political ends. That racialized thinking has led to the selection of legislation cannot be doubted, in the opinion of the author as stated in repeated passages. Of particular interest is the attention the author draws to the criminal activity that has now been identified as a result of recent innovations involving the crime of human smuggling and activity. As is demonstrated quite ably, it is difficult to distinguish between genuine efforts by sincere individuals motivated by laudable aims such as assisting refugees escaping persecution and the activities of modern-day pirates. Genuine concerns are raised that the broad definitions selected to deter this criminal endeavour will result in failing to assist genuine asylum seekers while driving many to attempt far too perilous trips to avoid detection. In short, the evidence she amasses and the conclusions she draws set forth a contemporary indictment that the criminal law of the present day continues to be enacted to further symbolic attacks on certain groups in order to both demonstrate a lessening of risk of violent behaviour by newcomers and a desire on the part of legislators to get tough on crime. In addition, I wish to commend Part 3: "Criminalizing Race" and the author's well-reasoned discussion of the fears that immigrants will be perceived in increasing instances as potential security risks without any corresponding increase in actual freedom from terrorists acts. In the final analysis, whether one agrees or not with Professor Chan's cogent analysis to the effect that criminal regulation continues at present to demonize certain categories of Canadians as was once the case, ${ }^{\sigma}$ the

$1 \quad$ On a narrower scale. that is to say the question of sentencing as communication, reference is made to the work of Professor R.A. Duff in his rightly celebrated text Trials and Punishmem (Cambridge: Cambridge University Press, 1986). For a recent commentary, sec Hendrik Kaptein. "Against the Pain of Punishment: Retribution as Reparation through Penal Servitude" in Hendrik Kaptein \& Marijke Malsch, eds., Crime. V'icsims and Jusfice: Essays on Principles and Practice (Burlington, Vt: : Ashgatc, 2004) 80. See also Sue Rex. "Punishment as Communication" in Anthony Bottoms, Sue Rex \& Gwen Robinson. Alternatives to Prison: Options for an Insecure Socicy (Cullompton, U.K.: Willan Publishing, 2004) 113.

3 See Terance D. Miethe \& Hong Lu, Punishmem: A Comparalive Historical Perspective (Cambridge: Cambridge University Press, 2005). See also the clear analysis offered by Professor Basia Spalek's article "Islam and Criminal Justice" in John Muncie \& David Wilson. eds., Student Handbook of Criminal Justice and Criminology (London: Cavendish Publishing, 2004) 123.

4 See Susan C. Boyd, Dorothy E. Chunn \& Robert Menzies, eds.. (Ab/Using Power: The Canadian Experience, (Halifax: Fernwood Publishing, 200I). The situation in the United States touching upon the belief by the white majority in the South that lynching was not criminal provides a perfect example of the horrors that may be inflicted upon a minority group if the definition of a crime is not responsive to the needs of the community as a whole. Note the gripping accounts of multiple such exira-legal murders found in Ben Green, Before I/is Time: The Untold Siory of Ilarry T. Moore, America's first Civil Rights Margr, paperback ed. (Gainesville. Fla.: University Press of Florida. 2005) notably at 4547: Christopher Phillips \& Jason L. Pendleton, eds., The Union on Trial: The Political Journals of Judge William Barclay Napton, $1829-1883$ (Columbia, Mo.: University of Missouri Press, 2005) 441: and Ricardo C. Ainslie, Long Dark Road: Bill King and Murder in Jasper. Texas (Austin. Tex.: University of Texas Press. 2004) 
case she submits to the contrary cannot simply be ignored.

Steven Penney, law professor at the University of New Brunswick, authored the next essay "Crime, Copyright, and the Digital Age." The purpose pursued by Professor Penney was to describe and evaluate efforts to render criminal infringements of copyright in our digital era, in effect to demonstrate that the derisory enforcement efforts of the past may well give way to a concerted effort to penalize infringements and to make plain how such a result is brought about. Stated otherwise, the author wished to provide a concrete example of the precise motivations and justifications that lead to a Parliamentary response in one situation, copyright, and by necessary implication to demonstrate why other areas of concern, let us point to pollution or workplace safety by way of limited examples, have not garnered the same degree of legislative action. In the course of his able presentation, it becomes clear that criminal law is tributary to certain fundamental normative theories and that the absence of a reflex shared by the majority of the population to the effect that certain conduct is inherently wrong may doom enforcement efforts to failure. Further, what legislators must hope to achieve if a proposed enactment is to prove successful, is to address, or more properly to counter, the intuitive reaction of many when informed that certain commonplace conduct is prohibited: "Everybody does it." For example, if the vast numbers of young persons who download music are to change their ways, it will not be as a result of warning of six-figure fines that may be levied, but rather as a result of a successful campaign of enlightened argument to the effect that the industry will be ruined without drastic changes. In sum, Professor Penney's contribution provides a superb understanding of the challenges facing any legislative body seeking to modify conduct and an in-depth review of the mindset of the average individual whose conduct is sought to be influenced.

"Criminalization in Private: The Case of Insurance Fraud" by Professors Richard V. Ericson and Aaron Doyle examines the insurance industry and the effective means adopted to police and to criminalize policy holders by members of the industry and their initiatives in seeking legislative confirmation of their for-profit actions. Drawing in part on the massive and path-breaking work they published, together with Dean Barry, under the title Insurance as Governance, 'the authors seek to demonstrate how an industry's attempt at defining fraud and other misconduct against the background of increasing risk may be seen as a microcosm of how Canadian society may come to be governed. Is there any difference, save in degree. between the efforts of private security personnel to oust undesirable consumers from malls by castigating the activities of their targets as offences and the work of the insurance industry in re-casting heretofore well-accepted activity as now being inherently unacceptable? The authors, by examining the history of the so-called fraud problem, succeed in demonstrating that crime is a fundamentally contingent measure in the eyes of many institutions and that difficulties in defining acceptable behaviours, much less in ascertaining certain "unknowables" such as the extent of false claims, often result in efforts to legitimize "private justice" mechanisms. If the insurance industry can achieve a goal of denying claims by skillfully portraying marginal claims as demonstrating not just a strained justification, but also a criminal intent, the result is a subtle shift in the assignment of societal values. In other words, this mechanism results in demonizing the public at large and elevating the status of the corporate entity as a potential victim. Envisaged in this light, private crime definitions 
may well influence public views in the long run and, after all, the text is entitled "Defining Criminal Conduct."

The penultimate contribution, "From Practical Joker to Offender: Reflections on the Concept of 'Crime," by Pierre Rainville, the Vice Dean of Graduate Studies and Research at Université Laval, may well be the one text that will still be cited in the years to come by defence counsel. It is suggested that litigators will find it of ongoing assistance in that it contrasts with rare brio the discipline of law and the indiscipline of humour while making plain the many strands that link both, not unlike the solemn duties of sovereigns and the lampooning function of the court jester. More to the point in our effort at defining crime, how society views pie throwers communicates as much about our desire to restrict the scope of the criminal law as any traditional scholarly work. In this sense, Professor Rainville's attempt at defining the respective boundaries between questionable or derogatory behaviour and truly criminal behaviour is most felicitous. As a limited example, reference is made in the discussion at pages 134-137 as to the fine line that separates a bad joke from a hostile act in the context of an allegation of sexual violence and the conflicting perceptions of the joker and the victim. In addition, I commend the Cartesian skills on display in the selection of the themes that undergird the discussion, notably the categories of humour as drift (humour that degenerates), humour as pretense (humour that deceives) and humour as affront (humour that offends). In the final analysis, the author advances a thorough analysis of the risks associated with an overly broad interpretation of pranks and is to be thanked for arguing with vigour at page 146 that "[i]t is important to respect, as far as possible, [a] healthy quest for freedom and to establish 'unlegislated' zones for individuals."

The final contribution is no less worthy of commendation. Written by Queen's Sociology professor Laureen Snider, and entitled "Poisoned Water, Environmental Regulation, and Crime: Constituting the Nonculpable Subject in Walkerton, Ontario," it lays bare with remarkable acuity the challenge surrounding the non-objective nature of crime. In other words, we are asked why it is that certain minor elements of misconduct, two drunks cursing at each other on the public street in the early hours of the morning, commit a crime of causing a disturbance in the view of just about everyone, while massive deregulation of certain public safeguards touching upon vital areas of public life such as pollution are viewed as private areas insulated from the reach of criminal law. ${ }^{8}$ To track the author's words at the outset, we must examine how particular acts and actors come to be seen as non-criminal. The fundamental contribution of the author, leaving aside the painstaking review of the evidence presented during the inquiry, resides in the careful and comprehensive conclusions advanced as to the rationales of exoneration and why they may be resorted to in certain contexts seemingly without leave being sought in a regulatory context and why they appear as counterintuitive if not invasive in the traditional criminal law context. This essay has much to teach us and should prove of ongoing assistance in understanding the reach of the recent amendments to the Criminal Code of Canada touching upon corporate crimes and the criminal liability of organizations.

A recently published text carries forward this form of analysis to a degree that is most welcome. Sec Christine Parker el al. eds.. Regulating Lan' (Oxford: Oxford University Press, 2004). In particular. note Angus Corbett \& Stephen Bottomley, "Regulating Corporate Governance" 60.

R.S.C. 1985 , c. C.46. 
In conclusion, theorists such as Michel Foucault have observed: "[F]or the past 150 years the proclamation of the failure of the prison has always been accompanied by its maintenance." In other words, it is not by reason of the obvious historical failure of the criminal law to protect loved ones from assault at the hands of their domestic partners that Parliament will cease to legislate in this area and it is not by reason of the patent failure of laws to prohibit piracy of intellectual property that the legislative branch will discontinue its efforts to create new crimes to further certain societal or private interests. So it is with the seemingly inexorable work of legislators to enact new crimes to address new concerns (or contingencies, jt seems); the failure of a swath of laws creating crimes in the past will not be allowed to deter the work of future Parliamentarians.

Further, current research efforts in understanding how various groups conduct themselves, let us say organizations wielding great power over our lives, must be evaluated critically if we are to seek to protect ourselves from grave harms, on the one hand, and greater efforts must also be undertaken to restrict the criminalization of certain groups, let us say adolescent females, if it is shown that our contemporary means of defining criminal conduct serves to "catch and label" them as offenders to an undue and unfair degree, on the other. For example, research is demonstrating that young women resort to high rates of relational aggression spanning ostracism to social sabotage as a way of retaliating against others, particularly those of their gender. " Traditional research suggests that young male adolescents resort to direct violence in such instances. How we define a crime may result in overprosecuting the males while ignoring the no less harmful wrongs committed by the females.

In the final analysis, it is suggested that the mere fact of describing an activity as criminal is seen, in and of itself, as being socially positive and beneficial, irrespective of any actual benefit. 